CHINESE BUDDHISM 



\title{
CHINESE BUDDHISM
}

\author{
A Thematic History
}

Chün-fang Yü

\author{
HAN
}

University of Hawai i Press

Honolulu 
(C) 2020 University of Hawai'i Press

All rights reserved

Printed in the United States of America

$\begin{array}{llllllllllll}25 & 24 & 23 & 22 & 21 & 20 & 6 & 5 & 4 & 3 & 2 & 1\end{array}$

\section{Library of Congress Cataloging-in-Publication Data}

Names: Yü, Chün-fang, author.

Title: Chinese Buddhism : a thematic history / Chün-fang Yü.

Description: Honolulu : University of Hawai'i Press, 2020. | Includes bibliographical references and index.

Identifiers: LCCN 2020007860 | ISBN 9780824881580 (cloth) | ISBN

9780824883478 (paperback) | ISBN 9780824883508 (epub) | ISBN

9780824883492 (kindle edition) | ISBN 9780824883485 (pdf)

Subjects: LCSH: Buddhism-China.

Classification: LCC BQ44 .Y8 2020 | DDC 294.30951—dc23

LC record available at https://lccn.loc.gov/2020007860

Cover art: Guanyin. Northern Song Dynasty, ca. 1025.

Honolulu Museum of Art.

University of Hawai'i Press books are printed on acid-free paper and meet the guidelines for permanence and durability of the Council on Library Resources. 
For my students 
